\title{
薬剤師における調剤エラー要因と行動特性の関連
}

有田悦子, ${ }^{*}, a$ 細谷未佳, ${ }^{a}$ 谷古宇 $\quad$ 秀, ${ }^{b}$ 加賀谷 $\quad$ 肇, ${ }^{c}$ 河合典子, ${ }^{d}$ 近藤芳子 $a$

\section{The Association between Dispensing Error Factors and Behavioral Characteristics of Pharmacists}

\author{
Etsuko ARIta, ${ }^{*, a}$ Mika Hosoya, ${ }^{a}$ Shigeru Yakou, ${ }^{b}$ Hajime Kagaya, ${ }^{c}$ \\ Noriko KAWAI, ${ }^{d}$ and Yoshiko KonDO ${ }^{a}$ \\ Faculty of Pharmaceutical Science, Kitasato University, ${ }^{a}$ Department of Pharmacy, Tokyo Women's \\ Second Medical Hospital, ${ }^{b}$ Department of Pharmacy, Saiseikai Yokohama Nanbu \\ Hospital, ${ }^{c}$ Department of Pharmacy, Ofuna Chuo Hospital
}

(Received October 29, 2002; Accepted February 5, 2003)

\begin{abstract}
We evaluated error prevention education by clarifying the association between dispensing error factors and behavioral characteristics of pharmacists. The subjects were 98 pharmacists ( 27 men and 71 women) with a mean age of 29.7 years who gave informed consent for participation in our survey. Between November 2001 and January 2002, a questionnaire survey on dispensing errors was performed using the "Tokyo University Egogram, New Version" for the assessment of behavioral characteristics and the "Safety Behavior Questionnaire" for the assessment of error factors. An association was observed between the incidence of dispensing errors and behavioral characteristics. There was also an association between error contents and behavioral characteristics as well as error factors. With more experience, errors associated with becoming accustomed increased, suggesting that error prevention education is necessary not only for newly qualified pharmacists but also for managers.
\end{abstract}

Key words — dispensing errors; error prevention education; Tokyo University Egogram; safety behavior questionnaire

\section{緒 言}

近年，医療事故への社会的関心が高まりをみせ， 連日のようにマスメディアによる報道が行われてい る。特に調剤エラーに起因する医療事故防止対策が 薬剤師にとっては緊急の課題となっている. 日本薬 剂師会においても, 平成 13 年に「調剤事故防止マ ニュアル」1)が出され, 調剤過誤の原因や調剂事故 防止対策などがまとめられた。また，薬局における インシデントの集計・分析結果についても詳しく報 告されている. ${ }^{2)}$

我々が以前行った全国調査において, 調剤エラー の発生要因は 1. 調剂室の構造など環境面の問題,

2. 医薬品の規格・デザインの問題，3. 処方せん関 連事項, 4. 薬剂師自身の知識・スキルの問題, 5 . その時の体調や心理状態の問題，6. 薬剂師個人の

a) 北里大薬学部, b) 東京女子医大付属第二病院薬剂部,

c) 済生会横浜南部病院薬剤部, d) 大船中央病院薬剂部 e-mail: aritae@pharm.kitasato-u.ac.jp
性格特性の問題の 6 種類に大別された. ${ }^{3)}$ 調剤エ ラーを誘発する原因として薬局の物理的な構造など 組織としての取り組みが必要な $1-3$ のような外的 因子への対策や，4 のような専門知識や技能を高め るための教育は以前から重視されてきた。一方で, 5 や 6 のような個人の特性や心理状態などの内的因 子への対策は, 個々にゆだねられてきたのが現状で ある．航空業界や産業界などでは，機械を扱う“人” の内的因子への教育の必要性が既に重視されてい る. ${ }^{4)}$ 調剤や監査がヒトの手で行われている以上, 薬剤師に対しても個々人のエラー傾向や性格特性に 応じた教育が必要であると考える. ${ }^{5)}$

以前我々は，新人薬剤師の教育プログラム構築の 一環として研修期間中に調剤エラー調査を行い，エ ラー頻度が高い者と低い者の間では性格特性が異な ることを明らかにした。 ${ }^{6)}$ そこで今回は産業界で既 に用いられているエラー傾向を測るための調査用紙 を用い, 調剤エラー頻度とエラー内容やエラー要因 との関係を検討することを目的とした。 また，今回 
使用したエラー調査用紙を調剂エラー予防教育へ導 入する可能性の是非についても検討する.

\section{方法}

1. 対象調査協力の同意を得られた薬郕師 98 名（病院勤務 45 名, 調剂薬局勤務 53 名, 男性 27 名, 女性 71 名, 平均年齢 29.7 才）である. 被 験者の背景を Table 1 にまとめた.

\section{2. 調査方法 2001 年 11 月～2002 年 1 月にか} けて, エラー傾向を測る「安全行動調査票」, 性格 特性を測る「東大式エゴグラム新版」(TEG), 調 剤エラーに関するアンケート調査を, 記入方法を記 述した要旨とともに配布し, 後日回収した.

\section{3. 安全行動調査票の構成「安全行動調査票」} は産業界において個々人の特性に応じた安全管理を 行うための診断方法として正田らにより開発された 質問紙である. ${ }^{7-9)}$ 質問は 78 項目からなり，回答形 式は「はい」「いいえ」の 2 件法である.この回答 結果をもとに，4つのエラー傾向（E1 情報受容確 認, E2 意識中断, E3 忘却, E4 習慣行動), 8 つの パーソナリティ傾向 $(\mathrm{P} 1$ 疲れやすさ, P2 気の弱さ, P3 根気のなさ, P4いいかげんさ, P5 自制心の弱 さ，P6 軽率さ，P7 協調性のなさ，P8 神経質さ） 及び妥当性尺度について分析し, 個人のエラー傾向 やパーソナリティ傾向を客観的に示すものである. 各尺度は 6 点満点だが，尺度ごとに基準值が決まっ ており，最終的に 5 段階評価で診断される.

\section{TEG の構成 エゴグラムとは, 交流分析} 理論に基づき，個人の自我状態を批判的な親の自我 状態 (Critical Parent, CP), 養育的な親の自我状 態（Nurturing Parent, NP)，大人の自我状態 (Adult，A），自由なこどもの自我状態（Free Child， FC), 順応した子供の自我状態 (Adapted Child, AC) の 5 尺度に分け，それぞれが放出していると

Table 1. The background of Parmacists

\begin{tabular}{clclc}
\hline \hline 施設 & 区 分 & 対象者数 & 立 地 & 病床数 \\
\hline $\mathrm{A}$ & 薬局 & 45 & 関東地方 & なし \\
$\mathrm{B}$ & 薬局 & 8 & 関東地方 & なし \\
$\mathrm{C}$ & 病院 & 13 & 関東地方 & 500 床 \\
$\mathrm{D}$ & 大学病院 & 9 & 関東地方 & 404 床 \\
$\mathrm{E}$ & 病院 & 7 & 関東地方 & 166 床 \\
$\mathrm{F}$ & 大学病院 & 16 & 関東地方 & 1069 床 \\
\hline
\end{tabular}

思われる心的エネルギーの量を折れ線グラフで示し た Dusay が開発した性格特性の調査法である。10) CP は責任感の強さや自分への厳しさを, NP は思 いやりや優しさを，A は客観的な判断力や現実処 理能力を, $\mathrm{FC}$ は自己主張の強さや明るさを, $\mathrm{AC}$ は依存性の強さや協調性を示している.

今回用いた新版 TEG は，統計処理を行ったもの であり，1984 年に石川らによって報告されたもの に改良を加え 2000 年に刊行されたものである. 55 項目の質問項目に，はい，いいえ，どちらでもな い, の 3 件法で答え，その結果を尺度ごとに合計 し, 評価は尺度得点の高低と全体のプロフィールに よって行う。各尺度は 20 点満点となっており， Z 得点を用いた基準值に従って 5 段階評価で診断され る. ${ }^{11)}$

5. アンケートの構成 調剂エラーに関する質 問を中心に構成した（Table 2)。今回は，主に日常 のエラー頻度（問 4）と過去 1 年間の調剤エラーの 有無（問 6）を中心に検討した.

\section{結果}

1. 安全行動調査票の結果 安全行動調査の結 果を Fig. 1 にまとめた。対象となった薬剤師全体 では, エラー傾向もパーソナリティ傾向も平均的で あり，特徵的な傾向は見られなかった。

2. TEG の結果ＴEG の結果を Fig. 2 にまと めた。 TEG に関しても対象者全体では平均的なプ ロフィールを示しており, 薬剤師として特徵的な傾 向は見られなかった.

\section{3. アンケート調査結果との検討}

3-1. 設問 4. あなたは, 日頃, 間違えて調剤しそ うになり，はっとすることがありますか？ “た まにある”と答えたものが 69\%おり，“非常によく ある”と答えた $5 \%$ と合わせると 7 割以上の薬剤師 が日頃からヒヤリ・ハットを経験している事が示唆 された。一方で“あまりない”と答えた者も $22 \%$ おり，ヒヤリ・ハットの頻度で 3 群に分け性格特性 やエラー傾向について検討を行った.

3-1-1. ヒヤリ・ハット頻度と安全行動調査結果 ヒヤリ・ハット頻度と安全行動調査票の結果につい て検討を行ったところ, “非常によくある”, “たま にある”と答えた者と“あまりない”と答えた者の エラー傾向では, 統計的な有意差は得られなかった 
Table 2. The questionaire about dispensing errors

各設問に対して, 当てはまる番号に○をつけて下さい.

問 1 あなたの身分は以下のどれに当たりますか.

(1) 経営者で管理薬剤師 (2) 管理薬剂師 (3) 薬剤師

問 2 あなたは，1日でおよそ何枚くらいの処方せんを応需しますか.
(1) 10 枚未満 (2) 50 枚未満 (3) 100 枚未満
(4) 150 枚末満
(5) 200 枚未満
(6) 200 枚以上

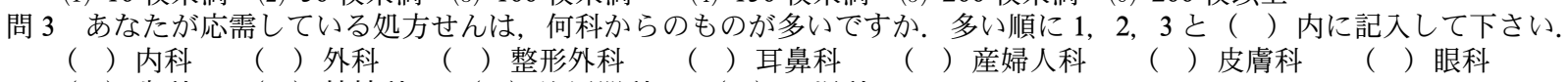
（ ）その他 (
( 泌尿器科
（）小肾科

問 4 あなたは，日頃，間違えて調剤しそうになり，ハットすることがありますか，
(1) 非常によくある
(2) たまにある
(3) あまりない
(4) 全くない

問 5 問 4 で(1), (2)を解答された方にお伺いします。

それは，どのような内容が多いですか，下記の項目から選び○をつけて下さい（いくつでも可）

1. 物理, 環境的な原因によるもの

(1) 薬の配置が近くにあったため, 取り間違えてしまった.

(2) 薬の名前が棚などにきちんと示されていなかったため, 間違えた.

(3) 調剂棚の正式な場所に別の薬が入っていたため間違えてしまった.

(4) その他 (

2. 薬の取り間違いによるもの

(1) 薬品の名称が似ているため間違えた.

(2) 同じ名称で別の規格のものを間違えた.

(3) 箱のパッケージや包装が似ているため間違えた。

(4) 薬の数を数え間違えた.

(5) 薬の量を計り間違えた。

(6) 充填する際, 別の薬を充填してしまった.

(7) 原薬名と一般名を間違えてしまった.

(8) その他 (

3. 処方せんの原因によるもの

(1) 疑義紹介を总ったため, 間違えてしまった.

(2) 処方せんの字が読みにくかったため, 読み間違えてしまった.

(3) 処方の一部分を見落としてしまった.

(9) その他 (

4. その他

(1) 調剂した薬を薬袋に入れ忘れた.

(2) 全く別の薬であるのに，それだと思い込んで調剤してしまった.

(3) 薬袋の表記を間違えてしまった。

(4) その他 (

問 6 あなたは, ここ 1 年間で, 間違えて調剤してしまったことがありますか.
(1)ある
(2)ない

問 7 問 6 で(1)と解答された方にお伺いします。

それは，どのような内容でしたか．下記の項目から選び○をつけて下さい．(いくつでも可）

1. 物理, 環境的な原因によるもの

(1) 薬の配置が近くにあったため, 取り間違えてしまった.

(2) 薬の名前が棚などにきちんと示されていなかったため, 間違えた。

(3) 調剂棚の正式な場所に別の薬が入っていたため間違えてしまった.

(4) その他 (

2. 薬の取り間違いによるもの

(1) 薬品の名称が似ているため間違えた.

(2) 同じ名称で別の規格のものを間違えた.

(3) 箱のパッケージや包装が似ているため間違えた.

(4) 薬の数を数え間違えた.

(5) 薬の量を計り間違えた.

(6) 充填する際, 別の薬を充填してしまった。

(7) 原薬名と一般名を間違えてしまった。

(8) その他 (

3. 処方せんの原因によるもの

(1) 疑義紹介を怠ったため, 間違えてしまった.

(2) 処方せんの字が読みにくかったため, 読み間違えてしまった.

(3) 処方の一部分を見落としてしまった.

(9) その他 (

4. その他

(1) 調剂した薬を薬袋に入れ忘れた.

(2) 全く別の薬であるのに，それだと思い込んで調剤してしまった.

(3) 薬袋の表記を間違えてしまった.

(4) その他 (

御協力ありがとうございました. 


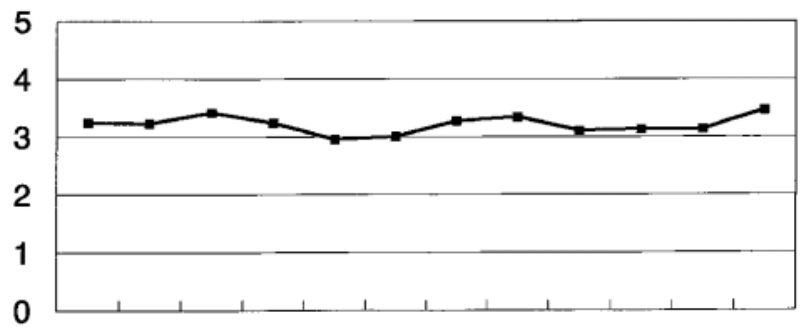

E1 E2 E3 E4 P1 P2 P3 P4 P5 P6 P7 P8

Fig. 1. The Average of Safety Behavior Research

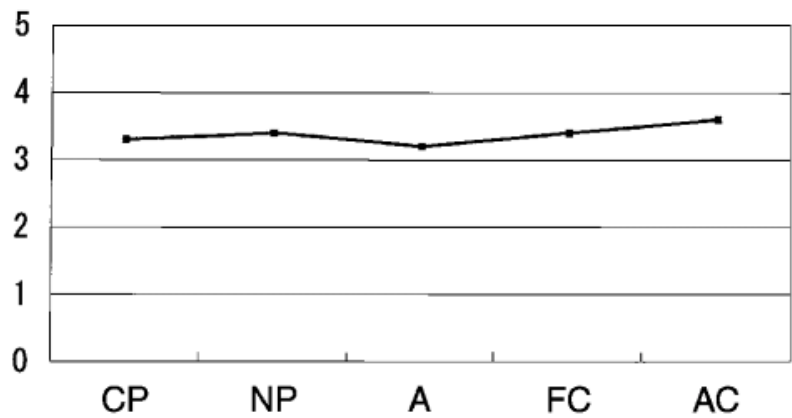

Fig. 2. The Average of Egograms

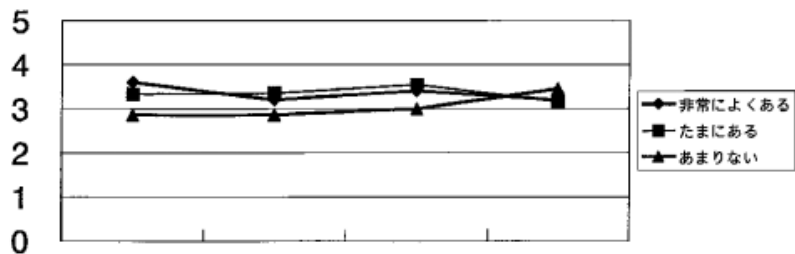

E1 E2 E3 $\quad$ E4

Fig. 3. The Frequency and the Tendency of Error

ものの，“あまりない”と答えた群が E1, E2, E3 と もに低い傾向が見られた（Fig. 3). パーソナリテ 个傾向では, $\mathrm{P} 2\left(p=0.002, \chi^{2}\right.$ 検定 $)$ と $\mathrm{P} 4(p=$ $0.008, \chi^{2}$ 検定）で“あまりない”と答えた群が “非常によくある”と答えた群に比して有意に低い 傾向が見られた（Fig. 4)。つまり，ヒヤリ・ハッ トとした経験があまりない群は，積極的でいい加減 でない性格傾向をもつことが示唆される，統計的な 有意差は見られなかったものの，P6 の軽卒さにつ いても低い傾向が見られる.

3-1-2. ヒヤリ・ハット頻度と性格特性ヒヤ リ・ハット頻度と TEG 評価について検討を行った ところ，“非常によくある”と答えた群と“あまり ない”と答えた群の間で $\mathrm{A}\left(p=0.016, \chi^{2}\right.$ 検定 $)$ と $\mathrm{AC}\left(p=0.002, \chi^{2}\right.$ 検定）に有意差が見られた（Fig. 5)。ヒヤリ・ハットした経験があまりない群は, 客

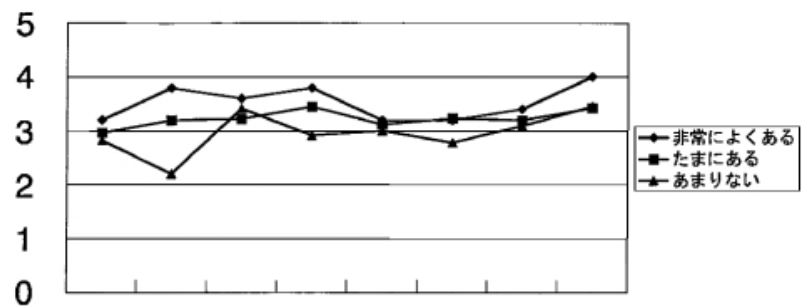

$\begin{array}{llllllll}\mathrm{P} 1 & \mathrm{P} 2 & \mathrm{P} 3 & \mathrm{P} 4 & \mathrm{P} 5 & \mathrm{P} 6 & \mathrm{P} 7 & \mathrm{P} 8\end{array}$

Fig. 4. The Frequency and the Tendency of Personality

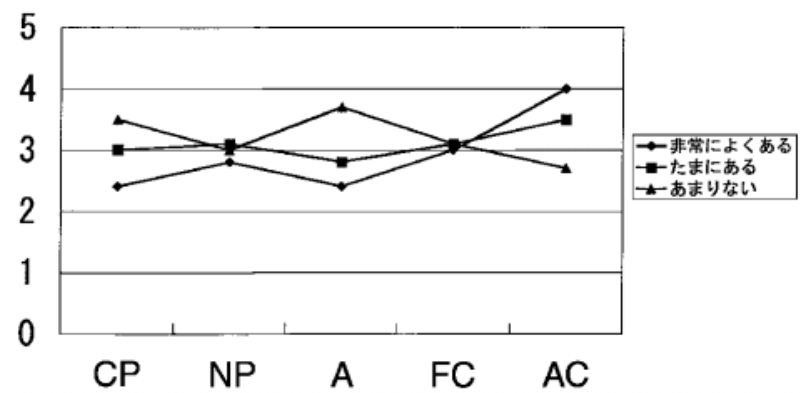

Fig. 5. The Frequency and TEG Score

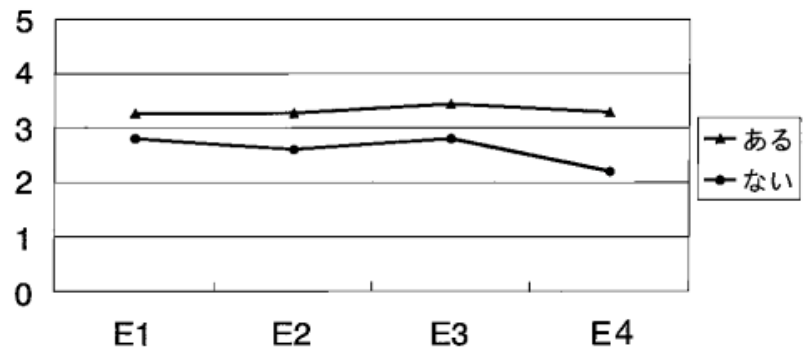

Fig. 6. The Tendency of Error between Non Error Group and Error Group

観的な判断力や現実処理能力が高く, 依存性が低い ことが示唆された。

3-2. 設問 6. ここ 1 年の間で，間違えて調剤した ことがありますか？ この 1 年間に調剤エラーを した群としない群の安全行動調査票の結果とエゴグ ラム評価を Figs. 6, 7 にまとめた。 最近 1 年間に調 剤エラーをした群は，しなかった群に比べて，安全 行動調査票のエラー傾向評価では全体に高いエラー 傾向を示し，エゴグラムの評価では，特に CP, A, FCで低い傾向を示した。

“ある”と答えた 91 名についてエラー内容をまと めた（Fig. 8)。一番多かつたのが「薬の計数間違 い」 $(27.7 \%)$ で，次に「同じ薬の規格間違い」 $(16.1 \%)$, 「薬の取り間違い」(15.2\%) が多かった. 個人の特性により，エラー内容に何らかの傾向が見 られるかを検討した。 
3-2-1. エラー内容と安全行動調査票エラー 内容とエラー傾向及びパーソナリティ傾向について 検討を行ったところ，いくつかの項目に相関 (Pearsonの相関係数) が見られた（Table 3, Table 4).

エラー傾向において「薬の計り間違え」には, $\mathrm{E} 2$ ：習慣行動， E3：意識中断，E4：忘却など色々

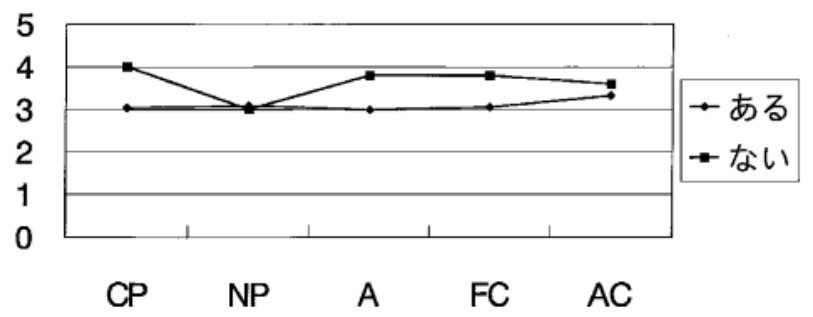

Fig. 7. The Comparison between Non Error Group and Error Group

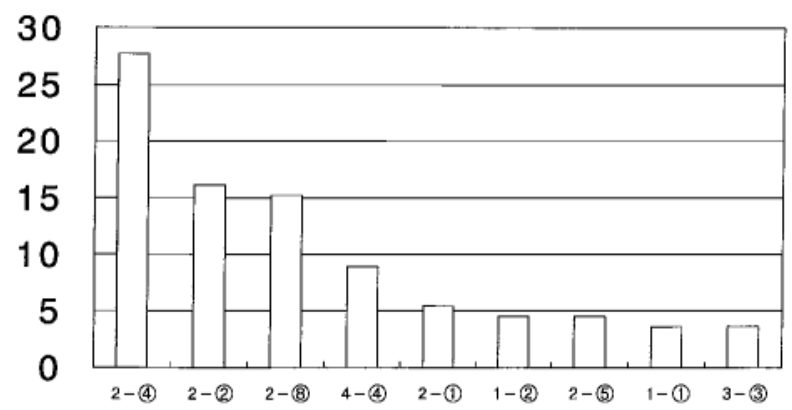

Fig. 8. The Error Contents (\%) (The 9 Largest)
な要因が絡んでいるのに対して，「処方せんの見落 とし」では，E1：確認ミスが主因となっており， 調剂エラーの内容を細かく検討していくことによ り，エラーの種類に対応した防止策や薬剤師教育の 指標が示された。

エラー内容とパーソナリテイ傾向との関連では, P3：根気のなさ, P5：自制心の弱さ, P7：協調性 のなさなども相関を示したが，一番多く関連性が示 されたのが, P4：いい加減さであり, 個人の特性 がエラー内容と深い関連があることが示唆された。

3-2-2. エラー内容と性格特性 エラー内容と TEG 評価について検討を行つたところ，いくつか の項目に相関（Pearsonの相関係数）が見られた (Table 5).

「原薬名と商品名の間違え」,「別の薬と思い込み」 などで CP と負の相関があり, 調剤に関してまず確 認や規律を守る重要性が示唆された。「その他の薬 剂師側原因」のエラーでは, CP と A で負の相関が あり, 調剤業務に関しては冷静な判断力や合理的な 思考が重視されることが示唆された。

\section{4. 安全行動調査票のエラー傾向に関する検討}

4-1. エラー傾向と性格特性 エラー傾向と TEG 評価について検討を行つたところ，E1 と CP, $\mathrm{E} 2$ と $\mathrm{A}, \mathrm{AC}, \mathrm{E} 3$ と $\mathrm{AC}$ との間に相関が見られた (Table 6).

$\mathrm{E} 1$ は聞き違いや見落としにつながるエラー因子

Table 3. The Correlation between Error Tendency and Error Contents

\begin{tabular}{l|rrrr}
\hline \hline & $\mathrm{E} 1$ & $\mathrm{E} 2$ & $\mathrm{E} 3$ & $\mathrm{E} 4$ \\
\hline 薬の量の計り間違え & 0.207 & $* * 0.313$ & $* 0.304$ & $* * 0.335$ \\
処方の一部見落とし & ${ }^{*} 0.286$ & -0.067 & 0.022 & -0.096 \\
処方せんの字が読みにくい & $* 0.251$ & 0.089 & 0.066 & 0.08 \\
\hline$* p<0.05,{ }^{* *} p<0.01$
\end{tabular}

Table 4. The Correlation between Personality Tendency and Error Contents

\begin{tabular}{l|ccrrrrrr}
\hline \hline & $\mathrm{P} 1$ & $\mathrm{P} 2$ & $\mathrm{P} 3$ & $\mathrm{P} 4$ & $\mathrm{P} 5$ & $\mathrm{P} 6$ & $\mathrm{P} 7$ & $\mathrm{P} 8$ \\
\hline 近くにある薬と間違えた & -0.1 & 0.042 & $* *-0.311$ & $* 0.235$ & 0.18 & -0.34 & $* 0.224$ & 0.006 \\
薬品名の表示が不適切 & -0.089 & 0.036 & -0.043 & -0.121 & $*-0.245$ & -0.137 & -0.097 & -0.022 \\
その他の物理・環境的原因 & -0.1 & -0.1 & 0.135 & $* 0.216$ & -0.006 & -0.017 & -0.126 & 0.065 \\
同じ名称で別規格を出した & 0.039 & -0.042 & $*-0.271$ & 0.033 & -0.062 & -0.022 & -0.046 & 0.08 \\
原薬名と商品名の間違え & -0.1 & -0.1 & 0.135 & $* 0.216$ & -0.006 & -0.017 & 0.084 & -0.184 \\
その他 (その他) & 0.146 & 0.053 & 0.194 & -0.132 & -0.02 & -0.128 & $* 0.246$ & 0.01 \\
\hline
\end{tabular}

$* p<0.05,{ }^{* *} p<0.01$ 
Table 5. The Correlation between TEG Score and Error Contents

\begin{tabular}{l|rccrr}
\hline \hline & $\mathrm{CP}$ & $\mathrm{NP}$ & $\mathrm{A}$ & $\mathrm{FC}$ & $\mathrm{AC}$ \\
\hline その他の物理・環境的原因 & -0.003 & -0.132 & -0.11 & $* 0.223$ & 0.078 \\
包装・パッケージの類似 & -0.005 & $* *-0.303$ & 0.061 & $* *-0.281$ & 0.067 \\
原薬名と商品名の間違え & $*-0.228$ & -0.253 & -0.11 & -0.122 & -0.161 \\
その他の薬剤師側の原因 & $*-0.225$ & -0.053 & $*-0.242$ & -0.031 & 0.036 \\
処方せんの字が読みにくい & -0.115 & $* 0.23$ & -0.001 & 0.108 & 0.198 \\
別の薬と思い込み & $*-0.244$ & -0.016 & -0.157 & -0.01 & 0.026 \\
薬袋の表記ミス & 0.316 & 0.07 & 0.153 & 0.072 & -0.059 \\
\hline
\end{tabular}

${ }^{*} p<0.05,{ }^{* *} p<0.01$

Table 6. The Correlation between TEG Score and Error Tendency

\begin{tabular}{l|ccrrr} 
& \multicolumn{1}{|c}{$\mathrm{CP}$} & $\mathrm{NP}$ & $\mathrm{A}$ & \multicolumn{1}{c}{$\mathrm{FC}$} & \multicolumn{1}{c}{$\mathrm{AC}$} \\
\hline \hline $\mathrm{E} 1$ (聞き違い・見落し) & $*-0.23$ & -0.15 & -0.067 & 0.011 & 0.185 \\
$\mathrm{E} 2$ (勘違い) & -0.119 & -0.03 & $* 0.216$ & -0.085 & $* * 0.362$ \\
E3 (ど忘れ) & -0.114 & 0.044 & -0.083 & 0.075 & $* 0.241$ \\
E4 (物忘れ) & -0.149 & -0.095 & 0.068 & -0.002 & 0.024 \\
\hline
\end{tabular}

* $p<0.05, * * p<0.01$

Table 7. The Correlation between Error Tendency and Experience Year

\begin{tabular}{l|cccc}
\hline \hline & $\mathrm{E} 1$ & $\mathrm{E} 2$ & $\mathrm{E} 3$ & $\mathrm{E} 4$ \\
\hline 経験年数 & -0.166 & $*-0.21$ & -0.005 & -0.075 \\
\hline$* p<0.05,{ }^{* *}$ & $p<0.01$ & & &
\end{tabular}

であり，CP の自他共に厳しい特性を伸ばすことに より，予防が可能であると考える。 また，E2 は勘 違いや思い込みにつながるエラー因子で，A が冷 静な判断力や論理的な思考の高さを示し, AC が依 存性の高さや気の弱さを示すことから，監査でミス を発見してくれるだろうという依存心や，いつもの 処方だという慣れを防ぐことで，習慣行動エラーは 予防できるのではないだろうか．E3 は集中力欠如 やど忘れなどにつながるエラーで，AC と関連があ ることから，調剤という仕事に関しては依存性の高 さはマイナスに働くことが再認識された。

4-2. エラー傾向と経験年数 エラー傾向と経 験年数について検討を行ったところ，E2 との間に 有意差 $\left(p=0.044, \chi^{2}\right.$ 検定）が見られた（Table 7).

\section{考察}

薬剤師が調剤を行う際，処方せんを読みこなして 適確な判断をするなどの頭脳労働と, 薬を取る, 量
るなどの肉体労働が同時に要求される，さらに，患 者さんが目の前で待っている時間的に切迫した状況 の中で，場合によっては問い合わせに答えたり，受 付をしたりなどの多重課題の労働を行っている.こ のように薬剤師を始めとする医療従事者の仕事に は，ミスを起こしやすい特徵的な背景があると言わ

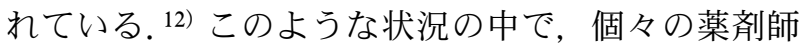
の行動傾向や性格特性の理解なしには, 本質的な事 故予防策は生まれてこないと考える.

ヒヤリ・ハット頻度との検討においては, パーソ ナリティ傾向の「気の弱さ」と「いい加減さ」に統 計的な有意差が見られた。「いい加減な」行動が調 剂エラーの原因になりやすいのは自明のこととし て，「気の弱い」人も，確認しなければいけないと ころで周囲に遠慮して確認できないなど，結果とし て調剤エラーを招く行動となる可能性がある，安全 行動調査で言うエラー傾向やパーソナリティ傾向 は，その人がエラーを起こす時の特徵的なものを示 しており，個人に対するエラー予防教育の一環とし て, 薬剤師教育に導入することで, 本人の自覚を促 す効果があると考えられる。

TEG については今回の調査においても，ヒヤ リ・ハット頻度が非常に高い群は低い群に比して, 冷静な判断力や客観的な処理能力を示す $\mathrm{A}$ が低 く，依存性や消極性を示す AC が高いと言う結果を 
得た。このことから，TEG で評価される性格特性 と調剤エラーの起こしやすさには関連があることが 改めて検証された.

薬剤師の教育カリキュラムの中に TEG を導入す ることで，各人が注意すべき性格特性について統計 的な裏づけに基づいた資料を得られ，指導者側だけ でなく本人が自分自身を客観的に振り返る機会にな ることが期待される。 また, TEG は対人交流の特 徵を分析するためにも有用であるので, 職場の対人 関係や指導者と新人の組み合わせなどの参考資料と しても用いる可能性も考えられる.

この 1 年間に実際に調剤エラーをした群は, 安全 行動調査票の結果からもエラー傾向が高い傾向を示 し, 安全行動調査票を事前に行うことによって, 事 前に注意を喚起する意義が示唆された，各人が陥り やすいエラー傾向を把握することは, エラー予防教 育の前提として大切なことであると考える.

調剤エラーの内容としては, 薬の取り間違いなど 薬剤師自身が原因となっているエラーが全体の 7 割 を占め, 調剤エラー予防のためには職場環境や紛ら わしい薬品名の整理と共に薬剤師の個人教育の重要 性が再認識された。

最後に, 薬剤師としての経験年数は慣れなどが要 因となる E2：習慣行動エラーと関連があったこと から, エラー防止の教育は, 新人のみならず, 管理 者に対しても重要であることが示唆された.

現在わが国で取り組まれている調剤エラー予防策 は，航空機関で使われている事故防止マニュアルを 参考に，医療の世界に応用しているものが多く，そ こでもヒューマンファクターが注目されている. ${ }^{14)}$ 具体的な取り組みとしては, インシデントアクシデ ントレポートをさらに踏み込んで, 作業者の内的心 理状態を調剂者自身によって分析，報告させること で，調剤過誤の減少に取り組む試みもなされてい る. ${ }^{15)}$ エラー発生の抑制を効果的に進めるには, 個 人別に行動傾向や性格特性を把握し, それに応じ て, 安全指導・教育を行うことが重要である. ${ }^{16)}$

今回用いた安全行動調査票は, もともと産業界で のエラー予防の目的で開発されたため, 質問項目が 薬剂師業務には適さないと思われるものもあった。 全体としてのエラー傾向などを把握するのには有用 であると考えるが，アンケート調査から得られた薬 剂師特有のエラー傾向を参考に, 今後より薬剤師に
適した質問項目を検討していく予定である.

医療従事者として薬剂師の社会的責任が増す中, ヒューマンエラーの個人差を有効に活用した調剤エ ラー予防教育はより一層重要になることが予想さ れ, 客観的評価尺度導入の有用性や具体的な利用法 など，今後更なる検討が必要であると考える.

\section{REFERENCES}

1) Nihonyakuzaishikai, "Yakkyoku Yakuzaishi no tameno Chouzaijiko Bousi Manual," 2001.

2) Nihonyakuzaishikai, Nihonyakuzaishikai Zasshi, 54, 83-91 (2002).

3) Ide J., Arita E., "Nihonyakugakkai Dai 122 Kai Youshishu 3," 2002, p. 206.

4) Oyama T., Maruyama M., "Human Error no Shinrigaku," Reitakudaigaku Shuppankai, 2001, pp. 143-147.

5) Masada W., “Anzenshinrigaku,” Kouseishakouseikaku, 1985, pp. 53-61.

6) Arita E., Sakamoto M., Ouchi Y., Komata S., Endou T., Kondo Y., "Creating a Training Program for New Pharmacists Making Uce of Individual Personality Characteristics First Report: Personality Characteristics of New Pharmacits and Their Training" Jpn. J. Pharm. Health Care Sci., 29 pp. 47-55 (2003)

7) Masada W., Watanabe K., Baba R., SangyoSoshiki Shinri Gakkai Dai 7kai Taikai Happyouronbunshu, 1991, pp. 68-73.

8) Harada Y., Masada W., Ouyousinrigakkai Dai 67 Kai Taikai Happyouronbunshu, 2000, p. 128.

9) Chuo Roudo Saigai Boushi Kyoukai, "Shin Sangyouanzen Hand Book," 2000, pp. 377381.

10) Dusay J. M., “Egogram,” Sougensha, 1995, pp. 19-53.

11) Tokyo Daigaku Igakubu Sinryounaika, "Shinpan TEG Kaisetsu to Egogram Pattern," 2002, pp. 15-36.

12) Oyama T., Maruyama M., "Human Error no Shinrigaku," Reitakudaigaku Shuppankai, 2001, pp. 14-16.

13) Masada W., "Sangyou Soshiki Shinrigaku," Kouseisha Kouseikaku, 1985, pp. 181-185.

14) Noma S., Hirayama T., Yamada Y., Hasegawa S., Matsuba K., “Gekkan Yakuji,” Vol. 
41, No. 11, Yakugyoujihousha, 1999, pp. 5157.

15) Kami K., Nurthing, 20, No. 5 (2000).
16) Yamauchi T., “Gekkan Yakuji,” 41, 43-50, (1999). 